\title{
Response of two wheat cultivars (triticum aestivum I) to amended nitrogen fertilizer on yield and grain quality in halfa elgadidah area
}

\begin{abstract}
A field experiment was conducted for two consecutive seasons during 2011/2012 and 2012/2013 on the Demonstration Farm of the Faculty of Agriculture, University of Kassala at New Halfa. The objective of the study was to investigate the interactive effects of cultivars and chicken manure with nitrogen fertilizer on yield and grain protein content of wheat cultivars (Triticum aestivum L). The wheat cultivars (Nepta and Bohein) were used, and the nitrogen fertilizer levels were $0,43,86 \mathrm{kgN} \mathrm{ha}^{-1}$ corresponding to N0, N1 and $\mathrm{N} 2$ without or with 2 tons of chicken manure ha ${ }^{-1}(\mathrm{M})$. The experiment was laid out according to split-plot design. Both cultivar, fertilizer treatments and their interactions showed significant increases in total leaf area duration and dry matter production. Also, Nebta cultivar out yielded Bohein by more than $20 \%$. Moreover, addition of organic manure with high $\mathrm{N}$ level significantly increased grain yield by more than $88 \%$ and $50 \%$ relative to N0 treatment for Nebta and Bohein, respectively. The increase in grain yield was associated with significant increases in yield components (number of grains plant ${ }^{-1}$ and 1000 -grain weight) and grain protein content.
\end{abstract}

Keywords: wheat; nitrogen, organic manure, cultivar, yield, water stress, correlation
Volume I Issue 5 - 2017

\author{
Badr ELdin Abdelgadir Mohamad Ahmed,' \\ Adam Ali Ishag, ${ }^{2}$ Mohmmed Kheir Hassan, ${ }^{2}$ \\ Mohmmed Othman Ahmed' \\ 'Department of Crop Science, University of Kassala, Sudan \\ ${ }^{2}$ Department of Crop Science, University of Red Sea, Sudan \\ ${ }^{2}$ Madani Research Station ARC, Sudan
}

Correspondence: Badr ELdin Abdelgadir Mohamad Ahmed, Department of Crop Science, University of Kassala, Sudan, Email hatoon2145@gmail.com, hatoon2145@live.com

Received: July 25, 2017 | Published: August 24, 2017

\section{Introduction}

Although, Sudan is considered as a marginal area of wheat production, the wheat crop ranks second after sorghum and now has become a strategic crop due to the shortage of food in the world and to the drastic change in the consumption habit of the people in Sudan..$^{1,2}$ Wheat is the main crop that provides protein and carbohydrates for many people. ${ }^{3}$ After cultivars, nitrogenous fertilizer is the second most important input for wheat crop growth and development. ${ }^{4}$ Although significant achievements have been made in production of wheat yield over the past several decades, requirements for higher-quality wheat have also increased as life styles have improved. ${ }^{5}$ Wheat production in Sudan is restricted by soil deficiencies in plant nutrients (especially nitrogen). Consequently adequate levels of nitrogen $(\mathrm{N})$ fertilizer are needed. ${ }^{6}$ Different studies have showed that decreasing $\mathrm{N}$ levels decreased grains yield per unit area in wheat. The importance of $\mathrm{N}$ fertilization in increasing wheat production has been well documented by many workers ${ }^{7,8}$ but still it is difficult to determine the quantities to apply with organic manure. On the other hand, application of organic manure has become an important tool used to increase crop yields and grain quality in intensive agricultural systems. ${ }^{9}$ Thus combined application of organic manure and nitrogen fertilizer can increase crop productivity through improving the chemical, physical and biological properties and nutrient status of the soil. The quantity and quality of cereal yields depend on the interacting numerous factors. One of these factors is the yield potential, which is manifested different areas under various growing conditions, depending on the adaptability of variety to unfavorable climatic conditions. Therefore, the best option for wheat production, yield improvement and yield stability under favorable fertilization is to use specific high yielding wheat cultivars. In view of the above reasons it was imperative to conduct experiment involving different wheat cultivars with regard to their response to low and high $\mathrm{N}$ nitrogen levels with or without chicken manure in order to obtain the potential grain yield of these cultivars. These factors interrelate providing an important insight to the study of their interaction on wheat production. Keeping these in view, an experiment was planned to study the effects of cultivars and nitrogen levels with or without chicken manure on yield and grain protein content of wheat.

\section{Materials and methods}

The proposed study was conducted on the Demonstration Farm of the Faulty of Agriculture, University of Kassala at New Halfa, Sudan (Latitude $15^{\circ} 19^{\prime} \mathrm{N}$. Longitude $35^{\circ} 36^{\prime} \mathrm{E}$ and Altitude $45 \mathrm{~m}$ asl). The experiment was laid out according to split-plot design with three replications. The main plots were allotted for cultivars treatments and the subplots for fertilizers treatments. The wheat cultivars used were Nebta (V1) and Bohein (V2), respectively. The nitrogen fertilizer (urea) levels were zero, 43, $86 \mathrm{kgN} \mathrm{ha}^{-1}$ coressponding to N0, N1 and $\mathrm{N} 2$ without or with 2 tons of chicken manure $\mathrm{ha}^{-1}(\mathrm{M})$. However, the total numbers of treatments were 18 in each replicate. The sub-plot size was $4 x 4 m^{2}$. Chicken manure was obtained from Dairy Farm at the Faculty of Agriculture, University of Kassala. The chemical composition of the manure was determined for the two seasons using Matrix Spinking Technique. ${ }^{10}$ All cultural practices done as recommended by Agricultural Research Corporation (ARC). Seeds were sown manually at a rate of $120 \mathrm{~kg} / \mathrm{ha}$, in three lines $15 \mathrm{~cm}$ apart, on the second week of November during both seasons. During the growth stage, the characters measured were Plant height $(\mathrm{cm})$, Shoot dry weight $\left(\mathrm{g} \mathrm{plant}^{-1}\right)$ and Leaf area duration $\left(\mathrm{dm}^{2}\right.$ days). Leaf area duration (LAD) was worked out according to the formula of. ${ }^{11}$ as follows: 
LAD: $\left(\mathrm{A}_{2}-\mathrm{A}_{1}\right)\left(\mathrm{t}_{2}-\mathrm{t}_{1}\right) /\left(\ln \mathrm{A}_{2}-\ln \mathrm{A}_{1}\right)$

Where: $\mathrm{A}_{1}$ : Leaf area at sampling time $\mathrm{t}_{1}, \mathrm{~A}_{2}$ : Leaf area at sampling time $\mathrm{t}_{2}$

$$
\mathrm{t}_{2}, \mathrm{t}_{1} \text { : time intervals in days between two stages. }
$$

At maturity, the characters measured were Number of grains plant $^{-1}, 1000$-grain weight $(\mathrm{g})$ and Grains yield $\left(\mathrm{Kg} \mathrm{ha}^{-1}\right)$. Also, protein content for grain estimated by using the improved Kjeldahl- method and crude protein percentage was calculated by multiplying the total nitrogen of the grain by 5.7 .

\section{Statistical analysis}

Data were statistically analyzed according to the analysis of variance (ANOVA) and mean comparisons at 5\% level of probability for split plot experiment using MStat-C computer software package. ${ }^{12}$

\section{Results and discussion}

Generally, it is quite visible from the data obtained in this study that cultivars exhibited a remarkable difference in their performance for growth parameters and yield components. Data shown in (Table 1) represented means of plant height, dry mater and leaf area duration (LAD) traits. From the obtained results, Nebta (V1) had a significantly greater plant height, dry matter and longer LAD than Bohein (V2). The significant increases in aforementioned characters in Nebta cultivar resulting in increases of yield and its attributes for such cultivar. In this regard, Nebta cultivar out yielded Bohein by more than 20\% (Table $1)$. The differences in grain yield between the cultivars are mainly due to differences in dry matter production and LAD. Supporting evidences were reported by ${ }^{13,14}$ who reported significant variations among the cultivars for number of grains and grain yield in wheat On the other hand, application of high $\mathrm{N}$ level solely or amended with chicken manure showed significant differences in both seasons (Table 1). In this regard, the tallest plants, high dry matter weight and longer LAD were recorded in plots fertilized with high $\mathrm{N}$ level mixed with chicken manure. Thus, the increase in these characters may be due to favorable effect of $\mathrm{N}$ on promoting vigorous plant growth and to the fact that chicken manure supplies direct available nutrients (i.e., N) to the plants and improvement of soil physical properties particularly Table I Interactive effects of cultivar and organic manure with or without nitrogen fertilizer on mean of some growth characters during 20I I/0I2 and 20I2/0I3 seasons in heavy clay soils as reported by. ${ }^{15}$ Moreover ${ }^{16,17}$ concluded that, application of nitrogen and organic manure hastened the dry matter accumulation which resulted in maximum LAD. This may support the findings of the present study where the addition of organic manure with high $\mathrm{N}$ level resulted in significant increase in aforementioned characters. In the present investigation, addition of chicken manure with high level of $\mathrm{N}$ resulted in an increase in number of grains per plant and 1000-grain weight of the two cultivars, the increase was substantial with Nebta cultivar (Table 2). Similarly addition of organic manure with high $\mathrm{N}$ level significantly increased grain yield by more than $65 \%, 50 \%$ and 39 relative to N0, N2 and MN0 treatments, respectively (Table 2). Regarding interaction cultivar $\mathrm{x}$ fertilizers treatments, addition organic manure with high $\mathrm{N}$ level to Nebta cultivar significantly increased the grain yield by more than $(72,55$ and 50$) \%$ relative to $\mathrm{N} 0, \mathrm{~N} 2$ and $\mathrm{MN} 0$ treatments, respectively (Table 2). Also, addition organic manure with high $\mathrm{N}$ level to Bohein cultivar significantly increased the grain yield by more than (45, 37 and 15$) \%$ relative to N0, N2 and MN0 treatments, respectively (Table2). However, the increase in grains yield was double through addition of MN2 to Nebta cultivar compared to none fertilized Bohein cultivar (Table 2). The increasing in growth characters resulting from applying high $\mathrm{N}$ level with organic manure may lead to the superiority in yield and its components. The increase in yield might be attributed to increase in number of grains plant ${ }^{-1}$ and 1000 -grain weight observed from these treatments. Moreover ${ }^{18}$ concluded that, application of organic manure with nitrogen increased grain yield by increasing dry matter production and LAD that resulted in maximum grain weight. This may support the findings of this study where addition of high $\mathrm{N}$ level with organic manure resulted in a significant increase of yield and its related characters. Furthermore, the substantial increase in grain protein content due to combination of organic manure with high nitrogen level was more clear in Nebta cultivar (Table2). This might be due to the increase in grain yield under such treatments as reported by. ${ }^{19,20}$ From the above results it is worthy to note that application of $\mathrm{N}$ and organic manure in combination has more advantages than applying alone i.e. when organic manure applied in combination helps in good crop growth, yield and good quality of grains compared to applying $\mathrm{N}$ or organic manure alone.

\begin{tabular}{lllllll}
\hline 20II/20I2 & & \multicolumn{5}{c}{ 20I I/20I3 } \\
\hline treatments & pnghtI & dwtI & LADI & pnght2 & dwt2 & LAD2 \\
VI & 53.56 & $4.3 I$ & 52.79 & 56.79 & $4.5 I$ & $44.4 I$ \\
V2 & $48.8 I$ & 2.42 & 36.46 & 50.52 & 3.42 & 37.72 \\
SE & 0.59 & 0.04 & 0.52 & 0.52 & 0.03 & 0.7 \\
LSD & $3.6 I$ & 0.28 & 3.18 & 3.18 & 0.16 & 4.25 \\
N0 & 44.53 & 2.13 & 37.02 & 48.9 & 2.78 & 32.27 \\
NI & 47.83 & 2.72 & 38.83 & 50.48 & 3.02 & 34 \\
N2 & 50.2 & 3.39 & 42.45 & 53.93 & 3.78 & 38.67 \\
MN0 & 51.67 & 3.55 & 43.91 & 52.62 & 4.15 & 39.39 \\
MNI & 54.27 & 3.58 & 48.27 & 55.8 & 4.69 & 45.79 \\
MN2 & 58.6 & 4.8 & 57.27 & 60.18 & $5.4 I$ & 56.29 \\
SE & 0.88 & 0.11 & 1.61 & 0.73 & 0.14 & 1.15 \\
\hline
\end{tabular}


Table Continued.

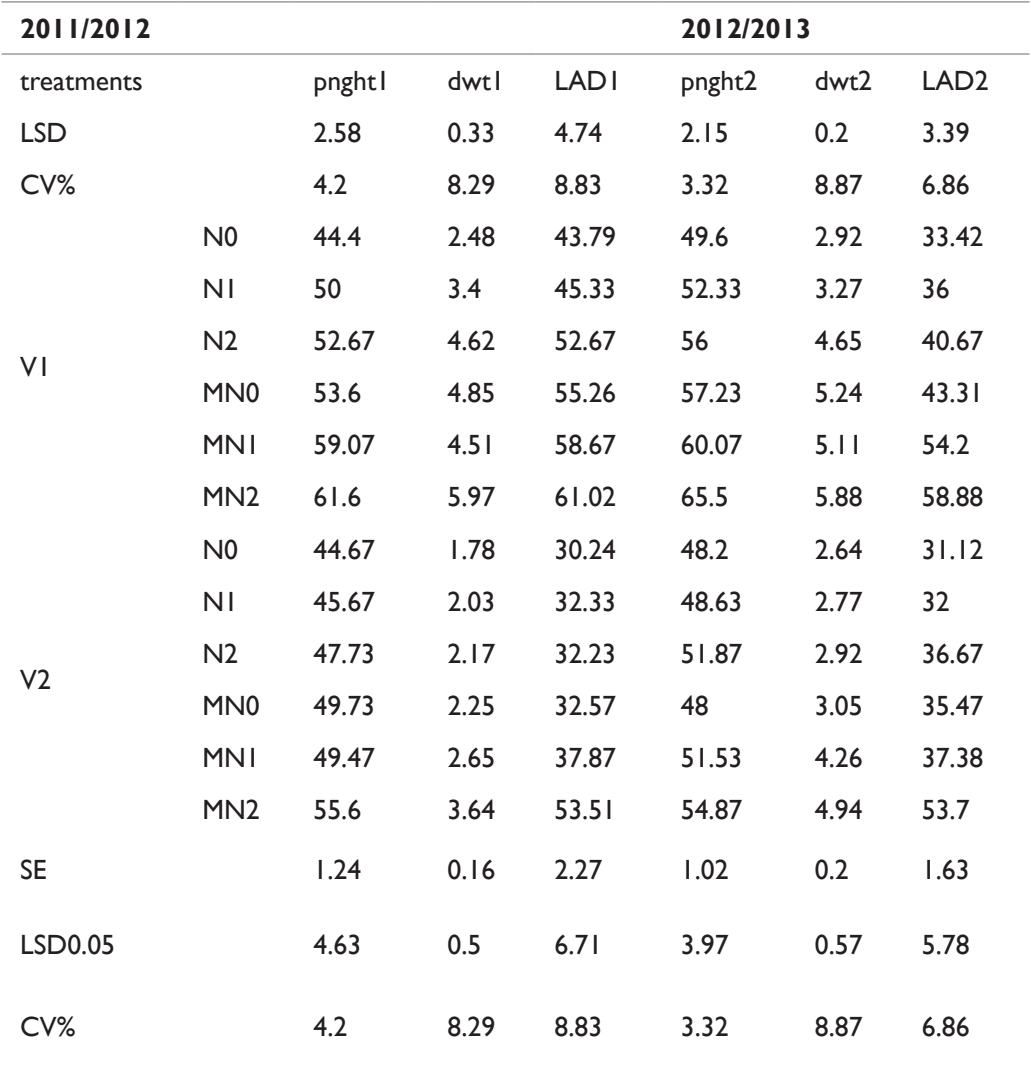

Table 2 Interactive effects of cultivar and organic manure with or without nitrogen fertilizer on mean of some wheat yield and its related characters during $2011 / 012$ and $2012 / 013$ seasons

\begin{tabular}{|c|c|c|c|c|c|c|c|c|}
\hline \multicolumn{5}{|l|}{$2011 / 2012$} & \multicolumn{4}{|l|}{$2012 / 2013$} \\
\hline treatments & $\begin{array}{l}\text { No.of grains } \\
\text { plant-I }\end{array}$ & $\begin{array}{l}\text { 1000-grain } \\
\text { (g) }\end{array}$ & $\begin{array}{l}\text { yield }(\mathrm{Kg} \\
\text { ha- } \mathrm{I})\end{array}$ & $\begin{array}{l}\text { Grain } \\
\text { protein\% }\end{array}$ & $\begin{array}{l}\text { No. of grains } \\
\text { plant-I }\end{array}$ & $\begin{array}{l}\text { 1000-grain } \\
\text { (g) }\end{array}$ & $\begin{array}{l}\text { yield }(\mathrm{Kg} \\
\text { ha-I) }\end{array}$ & $\begin{array}{l}\text { Grain } \\
\text { protein\% }\end{array}$ \\
\hline VI & 44.52 & 33.58 & 4567 & 13.17 & 47.22 & 34.86 & 4704.6 & $|3.5|$ \\
\hline V2 & 33.17 & 31.33 & 3641.6 & 12.4 & 41.22 & 33.48 & 3940.4 & $|2.6|$ \\
\hline SE & 0.4 & 0.42 & 125 & 0.1 & 0.38 & 0.16 & 60.3 & 0.2 \\
\hline LSD & 0.28 & 2.56 & 750.8 & 0.66 & 2.32 & 0.97 & 366.9 & 1.25 \\
\hline No & 33.47 & 29.16 & 3196.39 & 11.29 & 37.28 & 30.93 & 3546.21 & 11.9 \\
\hline $\mathrm{NI}$ & 34.5 & 30.75 & 3441.08 & 12.11 & 40.18 & 32.64 & 3623.57 & 12.23 \\
\hline N2 & 36 & 31.67 & 3663.91 & 13.06 & 41.82 & 33.31 & 3857.72 & 13.26 \\
\hline MNO & 36.72 & 31.59 & 3910.85 & 12.61 & 42.83 & 34.13 & 4243.76 & $12.7 \mid$ \\
\hline MNI & 43.85 & 35.38 & 4785.2 & 12.78 & 48.97 & 35.14 & $497 \mid .47$ & 13.24 \\
\hline MN2 & 50.7 & 36.19 & 5628.17 & 14.68 & 54.23 & 38.87 & 5692.27 & 15.04 \\
\hline SE & 1.27 & 0.4 & 139.3 & 0.18 & 0.47 & 0.46 & 137.7 & 0.14 \\
\hline LSD & 3.75 & 1.18 & 410.8 & 0.54 & 1.38 & 1.36 & 406.2 & 0.41 \\
\hline CV\% & 8.02 & 3.3 & 8.31 & 3.54 & 2.58 & 3.01 & 7.8 & 2.63 \\
\hline
\end{tabular}




\section{Conclusion}

When cultivar is not limited factor, combined application of organic manure with $\mathrm{N}$ fertilizer for wheat is a key factor to obtaining high biomass yields in the semi-arid environment, which translates to higher grain yield with greater protein content.

\section{Acknowledgements}

None.

\section{Conflict of interest}

The author declares no conflict of interest.

\section{References}

1. Ageeb OA, Badaruddin M, Reynolds MP. Wheat Management in Warm Environments. Agron J. 1997;91(6):975-983.

2. Ahmed BA. Interactive effects of water stress, Nitrogen fertilizer and chicken manure on growth, yield and water use efficiency of wheat (Triticum aestivum L.), University of Khartoum, Sudan: 2014.

3. World health organization. Energy and protein requirements. Technical report series No.522; Geneva: WHO; 1985.

4. Lenka S Singh AK, Lenka N. Water and nitrogen interaction on soil profile water extraction and ET in maize-wheat cropping system. Agricultural Water Management. 2009;96(2):195-207.

5. Park SH, Wilson JD, Seabourn BW. Starch granule size distribution of hard red winter and hard red spring wheat: Its effects on mixing and quality. J Cereal Sc. 2008;3:1-8.

6. Elsiddig K Ludders P, Ebert G, et al. Response of Rose Apple (Eugenia jampos L) to water and nitrogen supply. $J$ of Applied Botany. 1998;72:203-206.

7. Abedi I, Alam zadeh A, Kazemeini I. Wheat yield and grain protein response to nitrogen amount and timing Aust. J Crop Sci. 2011;5(3):330336.

8. Zhou J, Wang C, Zang H, et al. Effect of water saving management practices and nitrogen fertilizer rate on crop yield and water use efficiency in winter wheat-summer maize cropping system. Field Crop Research. 2011;122(2):157-163.
9. Andrews M, Lea PJ, Raven JA, et al. Can genetic manipulation of plant nitrogen assimilation enzymes result in increased crop yield and greater N use efficiency? An assessment. Annals of Applied Biology. 2004; $145: 25-40$.

10. Delavalle NB. Hand Book on Reference Methods for soil analysis quality assurance plans for agricultural testing laboratories. In: Athens GR, Soil and plants analysis council. 1992. p. 8-32.

11. Gardner FP, Pearce RB, Mitchell RL. Physiology of Crop Plants. 1st ed. Ames, USA: The Iowa State University Press; 1985. p. 201-207.

12. Nielsen G. Microsoft program for design, management and analysis of agronomy research experiment. USA: Michigan State University; 1992. p. 11-29.

13. Falaki AM, Miko S, Mohammed IB, et al. Evaluation of some improved bread wheat varieties at Chiyako, Jigawa state, Nigeria. ARPN J Agric Biol Sci. 2009;4(4):40-43.

14. Mohammad F, Ahmad I, Khan NU, et al. Comparative study of morphological traits in wheat and triticale. PakJ Bot. 2011;43:165-170.

15. Harris F. Management of manure in farming systems in semi-arid West Africa. Expl Agric. 2002;38:131-148.

16. Debatz S. Effects of nitrogen on yield and protein contents of Manitou and Pitic wheat grown under irrigation. Canadian Journal of Plant Science. 2000;52:887-890.

17. Jamaati SS, Roghayyoh ZM, Asgar Y, et al. Study of agronomical nitrogen use efficiency of durum wheat, affected by nitrogen fertilizer and plant density. World Applied Sci J. 2010;11(6):674-681.

18. Sadur Rehman A, Khalil K. Organic and inorganic fertilizaters increase wheat yield components and biomass under rain fed conditions. Sarhad J Agric. 2008;24(1):11-20.

19. Johnson VA, Mattern PJ. Wheat, rye and triticale In: Olson RA, et al. editors. The Nutritional Quality of Ceral Grains. Genetic and Agronomy improvement, USA: Springer; 1987. p. 133-182.

20. Upadhaya VB, Tiwari JP, Koshta LD, et al. Studies on correlation and regression of growth and yield of wheat (Triticum aestivum) varieties under late sown conditions. Res $J J K V V$. 1993;127:10-15. 